\title{
Respiration and deterioration of Inga vera ssp. affinis embryos stored at different temperatures ${ }^{1}$
}

\author{
Marcio Roberto Bonjovani², Claudio José Barbedo ${ }^{3 *}$
}

\begin{abstract}
Inga vera ssp. affinis embryos at different maturity stages and with various water contents had their $\mathrm{CO}_{2}$ production and $\mathrm{O}_{2}$ consumption analyzed, and then compared to those of Phaseolus vulgaris L. seeds. The results showed that the lower the temperature, the lower the respiratory rates and the more intense the other oxidative processes of $I$. vera embryos. On the other hand, the same did not happen in P. vulgaris seeds. Oxidative reactions, including respiration, reduced the germinative capacity and compromised the preservation of the embryos and seeds. Oxidative reactions depended on the embryo maturity stage, its moisture level, and the surrounding temperature. Interestingly, the responses obtained for viability loss and changes in $\mathrm{O}_{2}$ consumption rates of $I$. vera embryos did not correspond to the expected for plant tissues, as verified in P. vulgaris seeds with similar water content.
\end{abstract}

Index terms: oxidative processes, recalcitrant seeds, seed preservation.

\section{Respiração e deterioração de embriões de Inga vera ssp. affinis armazenados em diferentes temperaturas}

\begin{abstract}
RESUMO - Embriões de Inga vera ssp. affinis em diferentes estágios de maturação e com diferentes conteúdos de água tiveram sua produção de $\mathrm{CO}_{2}$ e consumo de $\mathrm{O}_{2}$ analisados e comparados com os de sementes de Phaseolus vulgaris L. Os resultados mostraram que quanto menor a temperatura, menor as taxas respiratórias e mais intensos os demais processos oxidativos dos embriões de $I$. vera. Por outro lado, o mesmo não aconteceu nas sementes de $P$. vulgaris. Reações oxidativas, incluindo a respiração, reduziram a capacidade germinativa e comprometeram a preservação de embriões e sementes. As reações oxidativas dependeram do estágio de maturidade do embrião, do seu nível de umidade e da temperatura ambiente. Curiosamente, as respostas obtidas para perda de viabilidade e mudanças nas taxas de consumo de $\mathrm{O}_{2}$ dos embriões de $I$. vera não corresponderam ao esperado para os tecidos vegetais, como verificado em sementes de $P$. vulgaris com teor de água semelhante.
\end{abstract}

Termos para indexação: processos oxidativos, sementes recalcitrantes, conservação de sementes.

\section{Introduction}

Recalcitrant seeds are difficult to be preserved during storage due to their sensitiveness to desiccation. Such a characteristic also poses a challenge for composing germplasm banks or including these plants in repopulation programs (Barbedo et al., 2013). In addition to that, studies on the conservation of these seeds are still inconclusive when it comes to the factors related to their short longevity.

The most efficient methods that have been used to improve conservation of these seeds consist of reducing

${ }^{1}$ Submitted on 04/07/2018. Accepted for publication on 09/18/2018.

${ }^{2}$ Secretaria da Educação do Estado de São Paulo, 01045-903 - São Paulo, SP, Brasil. the temperature (Bonjovani and Barbedo, 2008). Seeds dispersed that do not germinate inevitably begin to deteriorate, and the speed of this process depends mostly on the surrounding temperatures and water content of the seeds. In general, the higher the values of these factors, the faster the deterioration (Barbedo et al., 2018). Thus, by knowing the environment temperature and seed water content, it is possible to predict the storage time of a given species seed lot (Santos and Barbedo, 2017).

The accelerated metabolic activity of these seeds, since early stages of formation until their dispersion, probably has

${ }^{3}$ Instituto de Botânica, Núcleo de Pesquisa em Sementes, 04301-902 - São Paulo, SP, Brasil.

*Corresponding author<cjbarbedo@yahoo.com.br> 
an essential role in the deterioration process, especially when the water content is high (Barbedo et al., 2013; Caccere et al., 2013). Keeping this intense activity, especially under conditions of high ambient temperature, demands elevated respiratory rates and the consumption of seed reserves (Araújo and Barbedo, 2017).

During the period when seeds are metabolically very active, yet the germination has not started, a significant amount of free radicals, such as reactive oxygen species (ROS), can be released, contributing to increase the deterioration rate during storage (Walters et al., 2002). Nevertheless, there is little information corroborating this fact, as the results found in seeds of Salix nigra (Roqueiro et al., 2010; 2012). Besides that, high values of water content also favor microorganism growth, which can speed up the deterioration process (Kumar et al., 2015; Françoso and Barbedo, 2016; Parisi et al., 2016; Silva et al., 2017).

Inga vera Wild. ssp. affinis (DC.) T.D. Pennington, known as ingá, produces seeds that are sensitive to desiccation and naturally have low longevity (Caccere et al., 2013; Lamarca and Barbedo, 2015). Therefore, this species greatly interests studies aiming at the development of procedures to expand the storage potential of recalcitrant seeds. Researches have demonstrated that using specific techniques can extend the storage time of these seeds (Andréo et al., 2006; Faria et al., 2006; Bonjovani and Barbedo, 2008; Bonjovani and Barbedo, 2014; Parisi et al., 2016), but the knowledge on the physiology behind such improvement is still limited. A better comprehension of these processes could help to find new technologies that preserve the seeds for longer and that are also compatible with their preservation in germplasm banks.

On that account, considering the lack of information about the respiratory metabolism of recalcitrant seeds, the present work aimed at assessing the $\mathrm{O}_{2}$ consumption and $\mathrm{CO}_{2}$ release rates of $I$. vera embryos at different levels of hydration and subjected to different temperatures of incubation, thus analyzing their relationship with the preservation capacity of the seeds.

\section{Material and Methods}

\section{Obtaining the plant material}

Fruits of ingá (Inga vera Willd. ssp. affinis (DC.) T.D. Pennington) were collected from 10 trees that had been planted on Rodovia dos Bandeirantes, in the city of Jundiai,

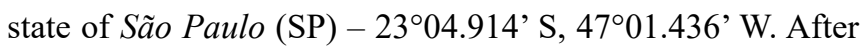
harvested, the fruits were processed in the Laboratory of Seeds at the Institute of Botany, based in São Paulo - 2337' $\mathrm{S}, 46^{\circ} 32^{\prime} \mathrm{W}$, where they were cut open and had their seeds manually removed. The seeds were grouped in three stages of maturation, designated as II, III, and IV (Bonjovani and Barbedo, 2008). Then, the sarcotesta was removed to obtain the embryos for use in the experiments.

The material was packed in plastic bags and then placed in a BOD chamber set at a constant temperature of $6{ }^{\circ} \mathrm{C}$, without light exposure, for up to seven days maximum, so all seeds collected could be extracted and processed (Bonjovani and Barbedo, 2008). In order to compare the results with those of seeds tolerant to desiccation, bean seeds (Phaseolus vulgaris L.) were used as a reference, once they belong to the same family (Leguminosae), but have an orthodox behavior. In this experiment, bean grains of the cultivar IPR 139, provided by the company Selegrãos, lot 037/11, were used.

\section{Physical and Physiological analyses}

First, the ingá embryos and bean seeds were characterized as for their water content, dry mass content (DM), germination, and electrical conductivity of the imbibition solution (EC). Water and dry mass contents were gravimetrically measured through the oven method at $103 \pm 1^{\circ} \mathrm{C}$ for $17 \mathrm{~h}$ (Brasil, 2009). Three replications with 10 ingá embryos each and four replications with 10 bean seeds were performed. The results of water and the dry mass contents were expressed as wet basis percentage and mg.seed ${ }^{-1}$, respectively.

The EC was determined with a digital conductivity meter MA150 (Marconi, Piracicaba, Brazil), in three replications with 10 ingá embryos and four replications with 10 bean seeds each. To do so, the materials were put in 300-mL plastic cups containing $75 \mathrm{~mL}$ of deionized water. After that, they were incubated for $24 \mathrm{~h}$ in a BOD chamber set at a constant temperature of $20^{\circ} \mathrm{C}$, in the absence of light. The results were expressed as $\mu \mathrm{S} . \mathrm{gDM}^{-1} . \mathrm{cm}^{-1}$ (Barbedo and Cicero, 1998).

The germination test was carried out in proper paper rolls, which had been moistened with distilled water at the amount of 2.5 times the dry paper weight. Three replications with 20 ingá embryos and four replications with 30 bean seeds were conducted. The rolls were kept in a germinator MA400 (Marconi, Piracicaba, Brazil), with internal water circulation, at a constant temperature of $25^{\circ} \mathrm{C}$ and continuous light (Brasil, 2009; Lamarca et al., 2013). Evaluations of the ingá embryos were conducted every two days, for 14 days. Since ingá seeds are polyembryonic, the embryos within a seed were kept together for the analyses, but only one germinated embryo was considered for each trial (Bonjovani and Barbedo, 2008). The germination test of the bean seeds was carried out according to Rules for Seed Testing (Brasil, 2009).

Respiratory rates and other oxidative reactions were estimated by assessing the consumption of oxygen $\left(\mathrm{O}_{2}\right)$ 
and production of carbon dioxide $\left(\mathrm{CO}_{2}\right)$ by the embryos or seeds incubated in respirometers. Those devices consisted in hermetically closed flasks, each one containing three holes on the lid. The lids were then covered with a rubber septum, which allowed introducing a sample-collecting needle, without exchanging air with the external surroundings (Lamarca and Barbedo, 2012).

The ingá embryos and bean seeds had their fresh mass and volume measured and were then transferred to the respirometers. When these containers were closed and stowed in BODs at pre-determined temperatures, the experiment started (time zero), assuming an average atmosphere composition $\left(21 \%\right.$ of $\mathrm{O}_{2}$ and $0.03 \%$ of $\left.\mathrm{CO}_{2}\right)$.

The samples of air from the flasks were evaluated in an analyzer Model 6600 (Illinois Instruments, Inc., Johnsburg, USA). The consumption of $\mathrm{O}_{2}$ and the production of $\mathrm{CO}_{2}$ in the respirometers were assessed by the difference between the measured values and those of the standard atmosphere. After each assessment, the containers were kept open for a few minutes to reestablish the equilibrium with the atmosphere, and then they were closed to proceed with the experiments. Considering 0.90 atm as the local atmospheric pressure, the percentage values obtained of $\mathrm{O}_{2}$ and $\mathrm{CO}_{2}$ were converted into the partial pressure of these gases (Lamarca and Barbedo, 2012).

After that, based on the volume of the packages and the temperature registered in each evaluation, the values were converted into micromoles of $\mathrm{O}_{2}$ and $\mathrm{CO}_{2}$ by the Clapeyron equation. According to previous experiments on the average daily consumption of $\mathrm{O}_{2}$ (and release of $\mathrm{CO}_{2}$ ) by ingá embryos and hydrated bean seeds (data not shown), the analyses were performed at one-day intervals, for materials incubated at positive temperatures in the treatments of each experiment (as following described), or every five days, for materials incubated at negative temperatures. The sum of the values obtained from these assessments was divided by the total dry mass of the embryo sample and by the number of days that the material remained in the packages. The outcome was expressed as micromoles per gram of dry mass per day $\left(\mu \mathrm{md} . \mathrm{gDM}^{-1} \cdot \mathrm{d}^{-1}\right)$. Also, the respiratory quotient (RQ) was calculated by dividing the amount of $\mathrm{CO}_{2}$ produced by the $\mathrm{O}_{2}$ consumed $\left(\mathrm{RQ}=\mathrm{CO}_{2} \cdot \mathrm{O}_{2}^{-1}\right)$, both in $\mu$ md.gDM ${ }^{-1} \cdot \mathrm{d}^{-1}$ (Kader and Saltveit, 2003).

Respiratory rates of ingá embryos submitted to different temperatures

To analyze the influence of temperature over the consumption of $\mathrm{O}_{2}$ and release of $\mathrm{CO}_{2}$, healthy embryos at stages II, III, and IV were incubated in flasks for up to 15 days at $-2,2,5,10$, and $15{ }^{\circ} \mathrm{C}$. By the end of this period, the embryos were physically and physiologically reassessed, as aforementioned. In a second experiment, aiming at evaluating the respiratory rates at temperature extremes, embryos at stage IV were incubated in respirometers, at temperatures varying from -21 to $24^{\circ} \mathrm{C}$. At the end, they had their viability evaluated.

Respiratory rates of bean seeds hydrated up to the same level as the ingá embryos

The respiratory rate of orthodox seeds presenting moisture content similar to that of recalcitrant seed embryos was analyzed. In this case, bean seeds with an $11.1 \%$ initial water content were incubated in distilled water, inside plastic trays (dimensioned $36.5 \times 26 \times 7 \mathrm{~cm}$ ) with nontransparent lids, and containing two germination paper sheets at the bottom. The seeds were then covered with a third paper sheet and remained submerged for $24 \mathrm{~h}$ inside a BOD chamber set at $6 \pm 1{ }^{\circ} \mathrm{C}$. By the end of the incubation period, they had reached a $57 \%$ water content. Then, the superficial water excess was drained with the aid of some filter paper, and the seeds were stored in glass containers, as previously described. Last, they were incubated at different temperatures for up to 15 days, in order to assess the respiratory rates.

The ingá embryos initially containing $61.4 \%$ of moisture were submitted to a light-drying in laboratory environment conditions $\left(24 \pm 2{ }^{\circ} \mathrm{C} / 40 \pm 5 \% \mathrm{RH}\right)$, until they reached a hydric potential of about $-4 \mathrm{MPa}$ (Bonjovani and Barbedo, 2008). The embryos achieved such condition after $36 \mathrm{~h}$, when their water content got to $54.4 \%$. Then, they were incubated in respirometers at temperatures from -3 to $15{ }^{\circ} \mathrm{C}$ for 15 days. After the incubation time, in order to evaluate the respiratory rates, bean seeds and ingá embryos were physically and physiologically reassessed, as previously described.

\section{Experimental design and statistical analysis of the data}

The experiment was performed in a completely randomized design. Three and four replications were carried out for the trials with ingá and beans, respectively. The results were analyzed by using the $\mathrm{F}$ test, and the means were compared through the Tukey's test, at a 5\% significance level (Santana and Ranal, 2004).

\section{Results and Discussion}

At the moment of harvest, ingá embryos had water contents of $68.8,64.2$, and $61.4 \%$, and dry mass contents of $0.23,0.34$, and 0.30 g.seed $^{-1}$, at stages II, III, and IV, respectively. The percentages of seeds able to protrude the radicle (botanical germination), corresponding to these stages, were 90, 97,

Journal of Seed Science, v.41, n.1, p.044-053, 2019 
and $90 \%$, while the values of germination (normal seedling development) were 47,97 , and $85 \%$, respectively. Such outcomes validate the evolution of maturation throughout the stages, as reported by Bonjovani and Barbedo (2008).

The water content of the embryos during incubation at different temperatures oscillated by less than $2 \%$, and the dry mass content remained practically constant, meaning that it was not possible to detect consumption of seed reserves. In spite of that, the results on $\mathrm{O}_{2}$ consumption and $\mathrm{CO}_{2}$ release of embryos incubated at -2 to $15^{\circ} \mathrm{C}$ showed intense metabolic activity, probably respiratory, especially at the highest temperatures (Figure 1). As the temperature was reduced, the production of $\mathrm{CO}_{2}$ also declined (Figures 1A-C). This behavior was expected due to the deceleration of enzymatic reactions, which affects the respiratory rates (Taiz and Zeiger, 2012). It is worth noticing that the $\mathrm{CO}_{2}$ release occurred at negative temperatures $\left(-2^{\circ} \mathrm{C}\right)$ as well. This fact could be an explanation for the low capacity of preserving the viability of these seeds, even when they are stored at temperatures close to freezing (Faria et al., 2006; Bonjovani and Barbedo, 2008).
On the other hand, the $\mathrm{O}_{2}$ intake did not follow the $\mathrm{CO}_{2}$ release. In general, two distinct levels of consumption were observed: a higher one at the positive temperatures (150 to 250 $\left.\mu \mathrm{mol} . \mathrm{gDM}^{-1} \cdot \mathrm{d}^{-1}\right)$, and a lower one at the negative temperatures (from 40 to $50 \mu \mathrm{mol}_{\mathrm{gDM}} \mathrm{gD}^{-1} \cdot \mathrm{d}^{-1}$ ) (Figures 1D-F). The sudden change in $\mathrm{O}_{2}$ consumption might be the consequence of water freezing, once it can increase the difficulty for gas diffusion (Pagnotta and Bruni, 2006) or even cause the death of cells. However, the high $\mathrm{O}_{2}$ consumption displayed during the temperature reduction, while $\mathrm{CO}_{2}$ release rates decreased progressively, is possibly an indication that oxidative reactions not-related to respiration had occurred. This fact became more evident when the RQ was calculated, since the lower the temperature, the lower the values of this feature (Figures 1G-I). Besides, even when the $\mathrm{CO}_{2}$ production was high (at temperatures above $10{ }^{\circ} \mathrm{C}$ ), it was still much lower than the $\mathrm{O}_{2}$ intake.

The 15-day incubation period at different temperatures did not alter the germinative capacity of the embryos, except when it was carried out at $-2{ }^{\circ} \mathrm{C}$ (Figure 2). Therefore, it is
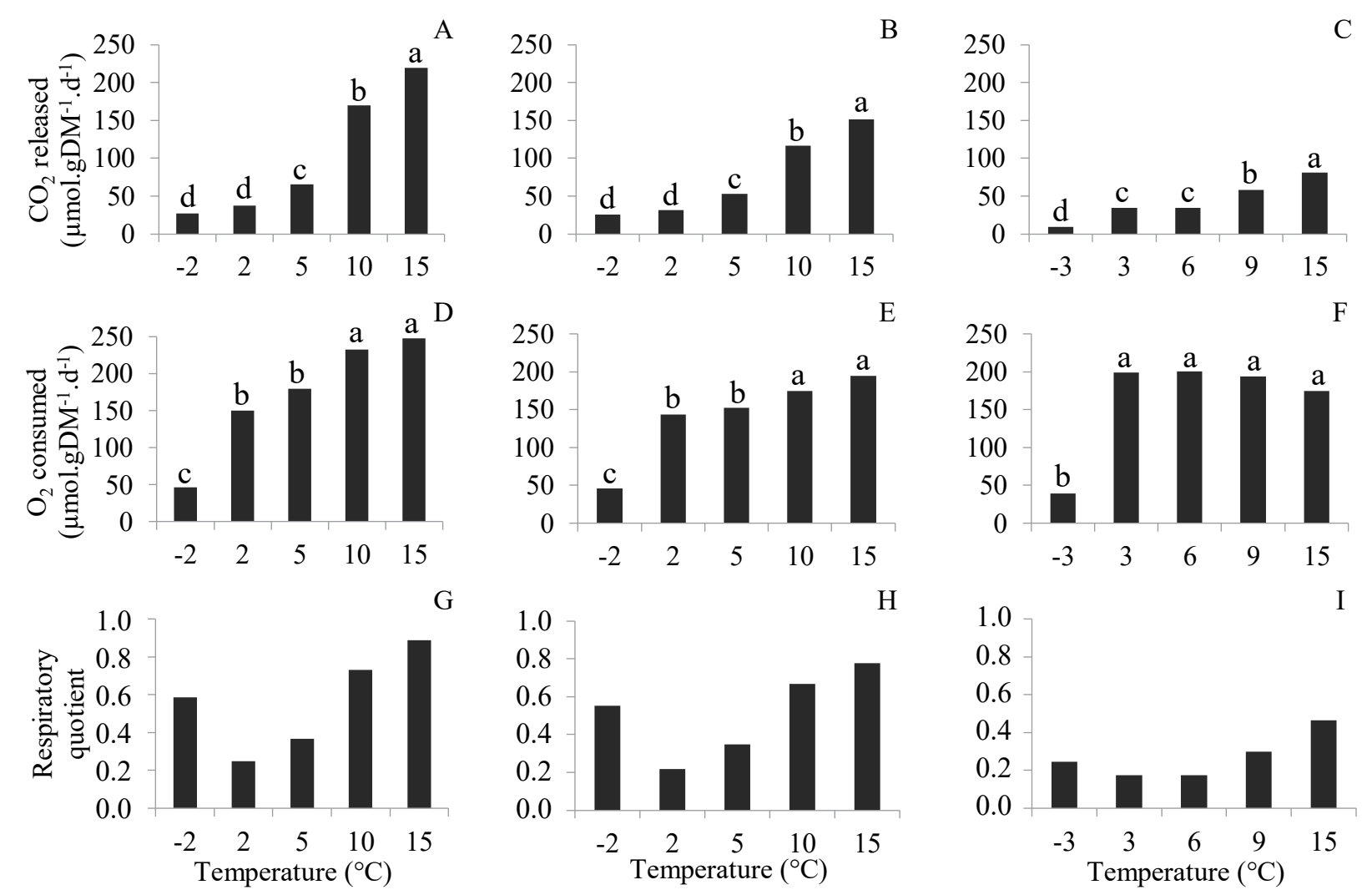

Figure 1. $\mathrm{CO}_{2}$ release $(\mathrm{A}, \mathrm{B}$, and $\mathrm{C}), \mathrm{O}_{2}$ consumption $(\mathrm{D}, \mathrm{E}$, and $\mathrm{F})$, and respiratory quotient $(\mathrm{G}, \mathrm{H}$, and I) of Inga vera embryos at stages II (A, D, and G), III (B, E, and H), and IV (C, F, and I), with $68.8 \%, 64.2 \%$, and $61.4 \%$ water content, respectively, after a 15 -day incubation period at different temperatures. Values followed by the same letter statistically do not differ, according to the Tukey's test at a 5\% significance level.. 
possible to assume that the mass capable of performing respiration at positive temperatures remained unaltered throughout the experiment.

The same metabolic activity pattern could be observed in stage-IV embryos incubated at a broader temperature gradient (from -21 to $24^{\circ} \mathrm{C}$, Figure 3). As the temperature was reduced, the $\mathrm{CO}_{2}$ production also decreased progressively (Figure $3 \mathrm{~A}$ ). On the other hand, the $\mathrm{O}_{2}$ consumption was lower at negative temperatures, showing the highest values up from $0{ }^{\circ} \mathrm{C}$ (Figure 3B). The outcome was that the lower the temperature used, the lower the RQ obtained (Figure 3C).

An RQ value inferior to 1.0 and close to $0.6-0.7$ might indicate that lipids are being used by seeds in respiration, once the usage of saturated and unsaturated fatty acids as initial respiratory substrates demands larger quantities of $\mathrm{O}_{2}$ (Lamarca and Barbedo, 2012). However, ingá embryos possess a lipid content of only $0.27 \%$ (Mello et al., 2010), which is not enough for respiration. Thus, other non-respiratory oxidative reactions, such as peroxidation of lipids and oxidation of phenolic compounds releasing superoxide radical, can be involved in seed deterioration, although such a cause-effect relationship is not always noticed (Roach et al., 2010; Roqueiro et al., 2010; Gao et al., 2016).

Notwithstanding, during the incubation of embryos, the values of germination (Figures 2A-C) and electrical conductivity (Figures 2D-F) showed minimal variations at positive temperatures. This finding suggests that neither the selectivity efficiency of the membrane (EC variations below $\left.10 \mu \mathrm{S} . \mathrm{gDM}^{-1} \cdot \mathrm{cm}^{-1}\right)$ nor the germinative capacity of the seeds were affected by the high consumption of $\mathrm{O}_{2}$ during this period. The exception occurred at negative temperatures, at which the intracellular water might have frozen, causing cell rupture.

At the temperature range commonly used in seed preservation systems with artificially controlled environment (generally, below $10^{\circ} \mathrm{C}$ ), ingá embryos display low RQ values, which implies in a significant lack of balance between the $\mathrm{O}_{2}$ consumption and $\mathrm{CO}_{2}$ production (Figures 1G-I). Differently from what happens at high temperatures, at which the rapid deterioration is most likely caused by an intense metabolic activity that does not progress to germination, at low temperatures, the decay of ingá embryos is probably linked to oxidative processes.

Once no significant differences were noticed in normal seedling development or in the electrical conductivity of embryos incubated at positive temperatures by the end of the 15-day incubation period, it could be presumed that the result of the oxidative reactions was not immediate. In fact, previous works showed that ingá embryos could tolerate satisfactorily the first 15 to 30 days of storage at temperatures from 5 to $10{ }^{\circ} \mathrm{C}$ (Andréo et al., 2006; Faria et al., 2006; Bonjovani and Barbedo, 2008). However, after 30 to 60 days, their viability starts to decay more quickly (Bonjovani and Barbedo, 2008).

Embryos incubated at negative temperatures showed the highest values of electrical conductivity (Figures 2D-F and 3E), suggesting that the solution inside the cells probably got frozen, and consequently caused the rupture of membranes and leakage of solutes to the exterior medium. Such a fact was already expected, once the embryos were incubated with a
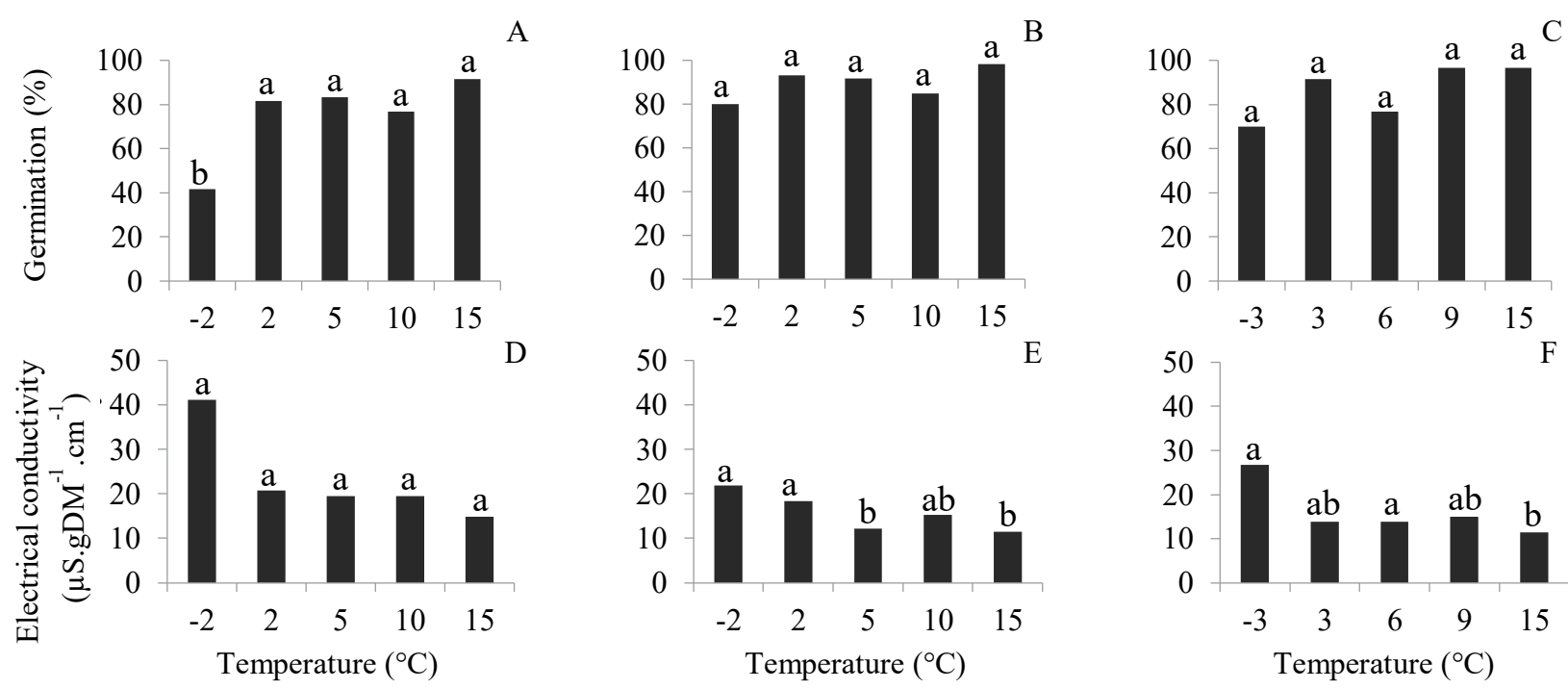

Figure 2. Germination (A, B, and C) and electrical conductivity (D, E, and F) of Inga vera embryos at stages II (A and D), III (B and E), and IV (C and F), with $68.8 \%, 64.2 \%$, and $61.4 \%$ water contente, respectively, after a 15 -day incubation period at different temperatures. Values followed by the same letter statistically do not differ, according to the Tukey's test at a $5 \%$ significance level. 
water content above $60 \%$, that is, with enough freezable water retained at tensions higher than -1.5 MPa (level-IV hydration, according to Vertucci and Farrant, 1995). At these levels, water becomes propense to freezing in both seeds tolerant and intolerant to desiccation, and it may cause damages due to ice crystal formation inside the tissues. The primary consequence of these ice crystals is the mechanic rupture of both the cytoplasmic structure and cell membrane caused by the expansion of water while freezing. The outcome is the cellular disaggregation, which leads to viability loss (Bonjovani and Barbedo, 2008; 2014; Taiz and Zeiger, 2012).

The germination results confirmed that maintaining the viability of embryos depends on the temperature. This fact evidenced their sensitivity to incubation conditions below $-2{ }^{\circ} \mathrm{C}$ (Figures 2A-C and 3D), especially when it comes to the stage-II embryos. Once there is no clear transition point between the maturation stages, it is valid to compare these findings to those obtained by Caccere et al. (2013), thus inferring that the stage-II embryos were in a development transition to maturity. That is, they were still immature, which could explain the high sensitivity to negative temperatures.

The bean seeds progressed from 11 to $56 \%$ water content after hydration, and they remained close to the latter value by the end of the 15-day incubation period at different temperatures (except for those kept at $15^{\circ} \mathrm{C}$, whose water content reached $60 \%$ ). As the temperature was reduced, their $\mathrm{CO}_{2}$ production
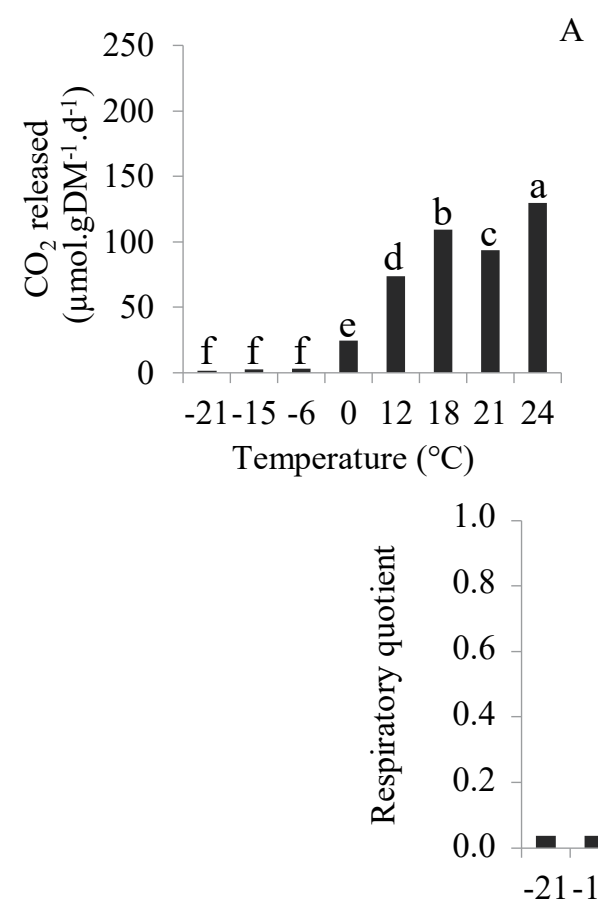

A

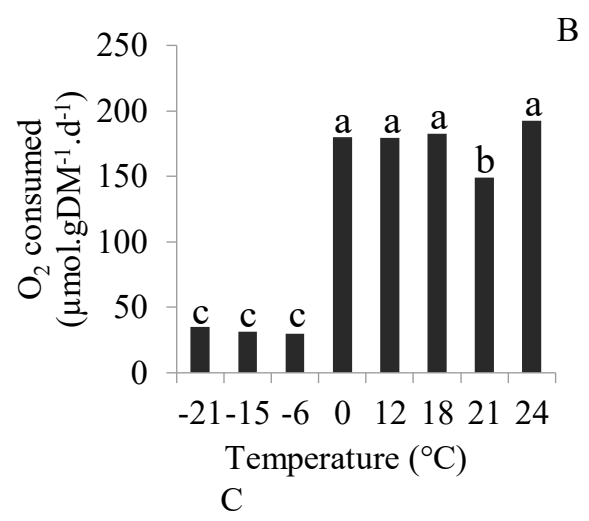

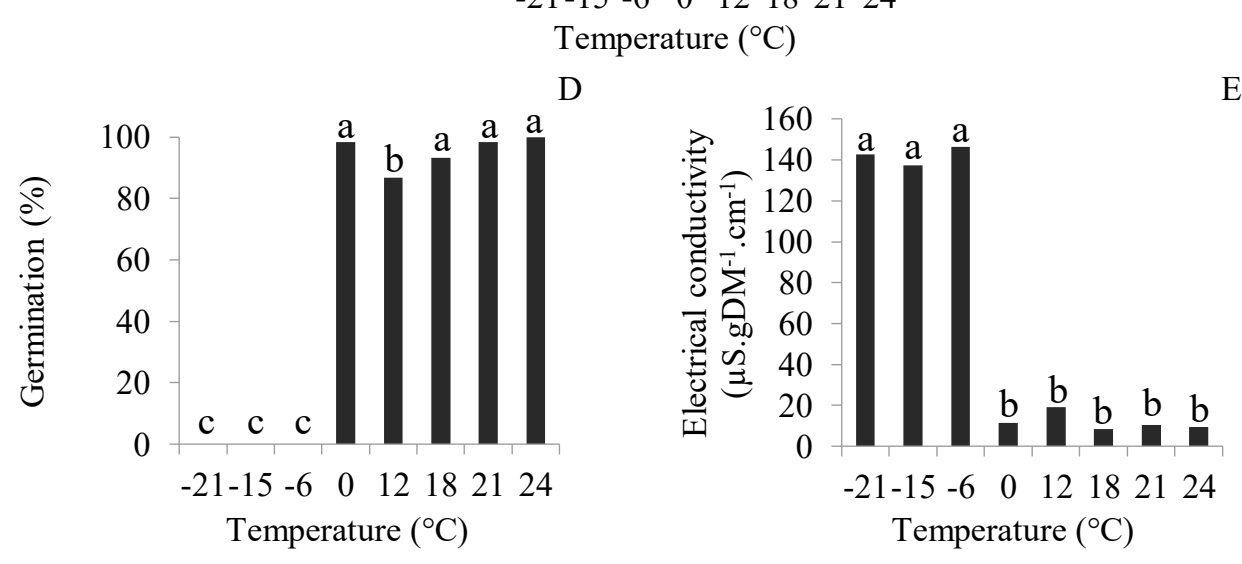

Figure 3. $\mathrm{CO}_{2}$ release $(\mathrm{A}), \mathrm{O}_{2}$ consumption (B), respiratory quotient (C), germination (D), and electrical conductivity (E) of Inga vera embryos at stage IV, with $61.4 \%$ water content, after a 15 -day incubation period at different temperatures. Values followed by the same letter do not differ statistically, according to the Tukey's test at a 5\% significance level. 
and $\mathrm{O}_{2}$ consumption also declined (Figures $4 \mathrm{~A}, \mathrm{C}$ ), and the respiratory activity decelerated. Such consequence was expected, since respiration starts after imbibition, but it can be delayed or slowed down by cold temperatures. It is important to remark that the abrupt change in $\mathrm{CO}_{2}$ release and $\mathrm{O}_{2}$ intake when the temperature was reduced from 15 to $9{ }^{\circ} \mathrm{C}$ (Figures $4 \mathrm{~A}, \mathrm{C})$ may be an indication that seeds were approaching the minimum germination temperature.

Curiously, the amount of germinated ingá seeds (approximately $80 \%$ ) was roughly twice as big as that of beans
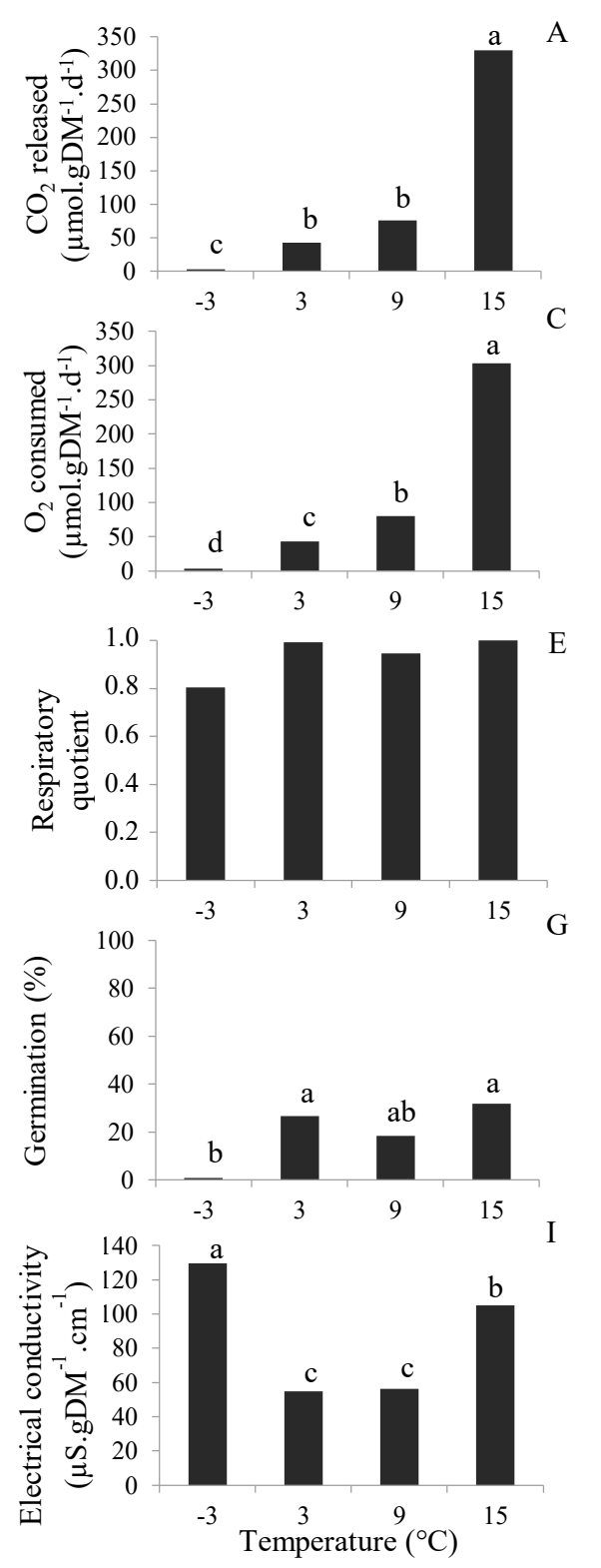

(around 40\%). Since the $\mathrm{O}_{2}$ consumption and $\mathrm{CO}_{2}$ release values are expressed in grams of dry mass per seed, the mass of bean seeds capable of performing respiration was smaller than that of ingá seeds. Nevertheless, the respiration rate at $15^{\circ} \mathrm{C}$ of the former was much higher than that of ingá embryos.

It is worth mentioning that the ingá seeds had been obtained by the end of their maturation phase, when the metabolism was still conditioned to produce seeds, whereas the bean seeds had been hydrated to start germination. In other words, the metabolism of ingá seeds was decelerating,
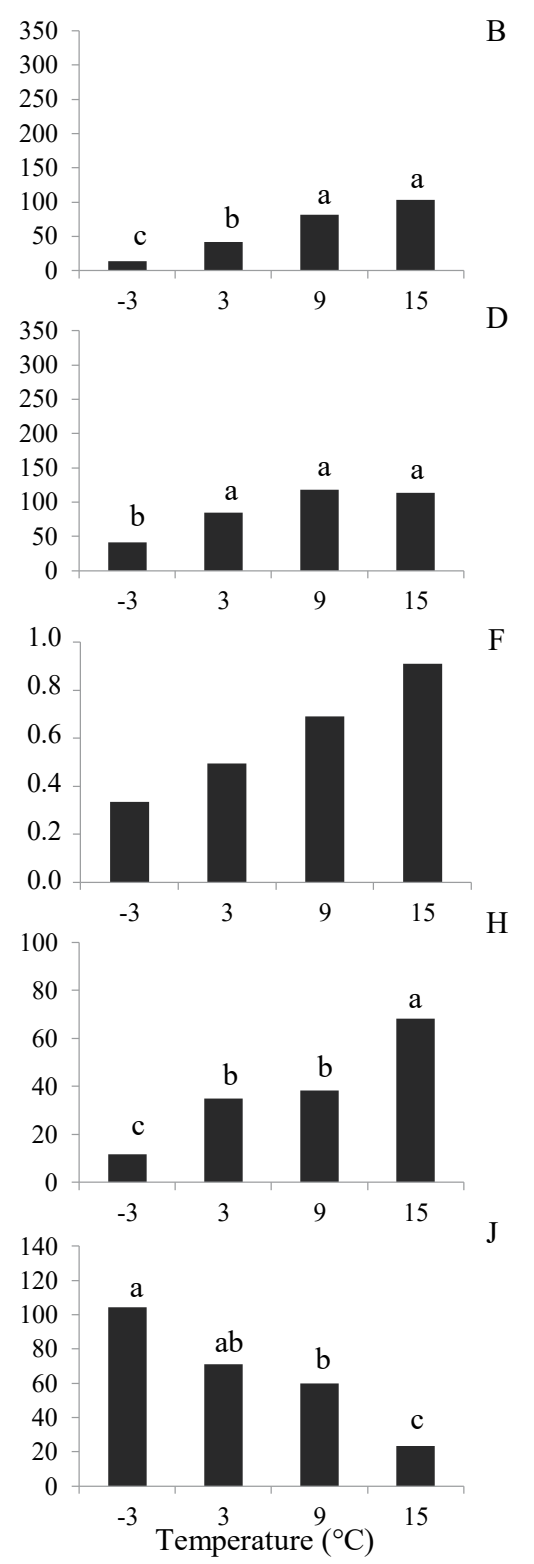

Figure 4. $\mathrm{CO}_{2}$ release $(\mathrm{A}$ and $\mathrm{B}), \mathrm{O}_{2}$ consuption $(\mathrm{C}$ and $\mathrm{D})$, respiratory quotient $(\mathrm{E}$ and $\mathrm{F})$, germination $(\mathrm{G}$ and $\mathrm{H})$, and electrical conductivity (I and J) of Phaseolus vulgaris seeds (A, C, E, G, and I) and Inga vera embryos (B, D, F, H, and J) with $56.6 \%$ and $54.4 \%$ water contente, respectively, after a 15 -day incubation period at different temperatures. Values followed by same letter do not differ statistically, according to the Tukey's test at a 5\% significance level. .

Journal of Seed Science, v.41, n.1, p.044-053, 2019 
while that of bean seeds it was getting more intense. This distinction probably explains the significant variation between the respiratory rates, once the embryos were in distinct physiologic processes.

It was also interesting that, at all temperatures assessed, the RQ values of the bean seeds were close to 1.0 (Figure 4E). This fact evidences the balance between $\mathrm{O}_{2}$ consumption and $\mathrm{CO}_{2}$ production (Lamarca and Barbedo, 2012). Different from the ingá seeds, whose water content was $54.4 \%$ (Figure $4 \mathrm{~F}$ ), no oxidative processes were observed in beans. Thus, the oxidative processes in ingá seeds do not merely result from their hydration state, yet they indicate a distinct metabolism from that of bean seeds. It is possible that reactive oxygen species have more impact on ingá seeds due to the inexistence of efficient antioxidant mechanisms. On the other hand, such systems are more complex and active in bean seeds.

As a matter of fact, as classic orthodox seeds, it is expected that beans possess well-developed antioxidative systems. Throughout their maturation process, the enzymatic systems for antioxidant defense are rearranged so that seeds can tolerate intense attacks of reactive oxygen species during desiccation. The same does not happen to recalcitrant seeds, as in ingá, and to the immature orthodox ones (Bailly, 2004 and references within; Chen et al., 2018; Dussert et al., 2018). Therefore, the difference between the metabolic state of ingá seeds in an incomplete maturation process (still without a fully developed antioxidant system) and that of bean seeds (with complete and operant systems) was once again evidenced (Barbedo et al., 2013; Barbedo, 2018).

The respiratory rates of ingá embryos showed that they remained active at the lowest temperature $\left(-3{ }^{\circ} \mathrm{C}\right)$, which could explain the difficulty in maintaining their viability in cold surroundings. In these conditions, even if no damage was caused by the drying process and considering that the temperatures are much lower than the germination optimum, seed metabolism could induce to hydric stress, once the continuity of such metabolic activity is similar to a situation of very slow germination. On account of that, there might not be enough free water for the processes of cell division and expansion, as predicted by Pammenter et al. (1994). If, on the one hand, reducing the temperature effectively decreases the respiratory rates, on the other, it also amplifies the oxidative processes, which can progressively speed up the deterioration (Kumar et al., 2015; Barbedo et al., 2018).

Thus, two respiratory metabolism patterns could be observed in ingá embryos and bean seeds with high water content $(55 \pm 2 \%)$. It became evident that such distinction was not connected to elevated water contents, but was most likely related to the inexistence or inefficiency of antioxidant systems in recalcitrant seeds. Barbedo (2018) point out as a possible explanation the fact that recalcitrant seeds behave similarly to immature orthodox ones, as observed in Libidibia ferrea ((Mart. ex Tul.) L.P. Queiroz) by Bragante et al. (2018). Therefore, ingá seeds would generally be dispersed without having concluded the maturation stage, so their antioxidant mechanisms remained underdeveloped.

The findings give an insight into the complexity related to viability loss in ingá seeds stored with high water contents and at low temperatures. Among several other aspects, they could help to explain many inconsistent data in the literature, once not always has the application of the same preservation techniques produced similar results. In the present work, the experiments evidenced the role of oxidative reactions, including respiration, in decreasing the germinative capacity and preservation potential of the seeds. It also became noticeable the influence of maturation stage, hydration level, and temperature on oxidative reactions occurring within the seeds. However, the outcomes of loss of viability and alterations in $\mathrm{O}_{2}$ consumption rates by ingá embryos did not correspond to those expected for plant tissues, even when they were contrasted to bean seeds with similar water content.

\section{Conclusions}

Reducing the storage temperature of Inga vera ssp. affinis embryos decreases their respiratory rates. However, it increases other oxidative processes that are related not only with the high-water content, but also with the recalcitrant behavior of these embryos.

\section{Acknowledgments}

The authors express their gratitude to Fapesp (Proc. 2005/04139-7) and CNPq (Proc. 481484/2007-8 and 477.640/2009) for the financial support; to Secretaria $d a$ Educação do Estado de São Paulo/Projeto Bolsa-Doutorado, for the scholarship granted to M.R. Bonjovani; to CNPq, for the scholarship granted to C.J. Barbedo; to CCR AutoBAn, for allowing and helping collecting the seeds.

\section{References}

ANDRÉO, Y.; NAKAGAWA, J.; BARBEDO, C.J. Mobilização de água e conservação da viabilidade de embriões de sementes recalcitrantes de ingá (Inga vera Willd. subsp. affinis (DC.) Pennington). Revista Brasileira de Botânica, v.29, p.309-318, 2006. http://www.scielo.br/pdf/rbb/v29n2/a12v29n2.pdf 
ARAÚJO, A.C.F.B.; BARBEDO, C.J. Changes is desiccation tolerance and respiratory rates of immature Caesalpinia echinata Lam. seeds. Journal of Seed Science, v.39, p.123-132, 2017. http:// www.scielo.br/pdf/jss/v39n2/2317-1545-jss-39-02-00123.pdf

BAILLY, C. Active oxygen species and antioxidants in seed biology. Seed Science Research, v.14, p.93-107, 2004. https://doi. org/10.1079/SSR2004159

BARBEDO, C.J. A new approach towards the so-called recalcitrant seeds. Journal of Seed Science, v.40, p.221-236, 2018. http://www. scielo.br/pdf/jss/v40n3/2317-1545-jss-40-03-221.pdf

BARBEDO, C.J.; CICERO, S.M. Utilização do teste de condutividade elétrica para previsão do potencial germinativo de sementes de ingá. Scientia Agricola, v.55, p.249-259, 1998. http:// dx.doi.org/10.1590/S0103-90161998000200013

BARBEDO, C.J.; CENTENO, D.C.; FIGUEIREDO-RIBEIRO, R.C.L. Do recalcitrant seeds really exist? Hoehnea, v.40, p.583-593, 2013. http://www.scielo.br/pdf/hoehnea/v40n4/01.pdf

BARBEDO, C.J.; SILVA, J.P.N.; FRANÇOSO, C.F.; PARISI, J.J.D. Armazenamento de sementes. In: BARBEDO, C.J., SANTOS JUNIOR, N.A. (Orgs.) Sementes do Brasil:produção e tecnologia para espécies da flora brasileira. São Paulo: Instituto de Botânica/ SMA, 2018. p.81-108.

BONJOVANI, M.R.; BARBEDO, C.J. Sementes recalcitrantes: intolerantes a baixas temperaturas? Embriões recalcitrantes de Inga vera Willd. subsp. affinis (DC.) T.D. Penn. toleram temperatura subzero. Revista Brasileira de Botânica, v.31, p.345-356, 2008. http:// www.scielo.br/pdf/rbb/v31n2/v31n2a17.pdf

BONJOVANI, M.R.; BARBEDO, C.J. Induction of tolerance to desiccation and to subzero temperatures in embryos of recalcitrant seeds of ingá. Journal of Seed Science, v.36, p.419-426, 2014. http:// www.scielo.br/pdf/jss/v36n4/a06v36n4.pdf

BRAGANTE, R.B.; HELL, A.F.; SILVA, J.P.N.; CENTENO, D.C.; FIGUEIREDO-RIBEIRO, R.C.L.; BARBEDO, C.J. Physiological and metabolic responses of immature and mature seeds of Libidibia ferrea ((Mart. ex Tul.) L.P. Queiroz) under contrasting storage temperatures. Brazilian Journal of Botany, v.41, p.43-55, 2018. https://doi.org/10.1007/s40415-018-0442-3

BRASIL. Ministério da Agricultura, Pecuária e Abastecimento. Regras para análise de sementes. Ministério da Agricultura, Pecuária e Abastecimento. Secretaria de Defesa Agropecuária. Brasília: MAPA/ACS, 2009. 395p. http://www.agricultura.gov.br/assuntos/ insumos-agropecuarios/arquivos-publicacoes-insumos/2946_ regras_analise_sementes.pdf

CACCERE, R.; TEIXEIRA, S.P.; CENTENO, D.C.; FIGUEIREDORIBEIRO, R.C.L.; BRAGA, M.R. Metabolic and structural changes during early maturation of Inga vera seeds are consistent with the lack of a desiccation phase. Journal of Plant Physiology, v.170, p.791-800, 2013. https://doi.org/10.1016/j.jplph.2013.01.002

CHEN, L.; WANG, Z.; LI, M.; MA, X.; TIAN, E.; SUN, A. Analysis of the natural dehydration mechanism during middle and late stages of wheat seeds development by some physiological traits and iTRAQ-based proteomic. Journal of Cereal Science, v.80, p.102110, 2018. https://doi.org/10.1016/j.jcs.2017.12.015
DUSSERT, S.; SERRET, J.; BASTOS-SIQUEIRA, A.; MORCILLO, F.; DÉCHAMP, E.; ROFIDAL, V.; LASHERMES, P.; ETIENNE, H.; JOËT, T. Integrative analysis of the late maturation programme and desiccation tolerance mechanisms in intermediate coffee seeds. Journal of Experimental Botany, v.69, p.1583-1597, 2018. https:// academic.oup.com/jxb/article/69/7/1583/4816236

FARIA, J.M.R.; DAVIDE, L.C.; SILVA, E.A.A.; DAVIDE, A.C.; PEREIRA, R.C.; VAN LAMMEREN, A.A.M.; HILHORST, H.W.M. Physiological and cytological aspects of Inga vera subsp. affinis embryos during storage. Brazilian Journal of Plant Physiology, v.18, p.503-513, 2006. http://www.scielo.br/pdf/ bjpp/v18n4/08.pdf

FRANÇOSO, C.F.; BARBEDO, C.J. Osmotic and heat treatments on control of fungi associated with seeds of Eugenia brasiliensis and E. pyriformis (Myrtaceae). Journal of Seed Science, v.38, p.195-203, 2016. http://www.scielo.br/pdf/jss/v38n3/2317-1545-jssv38n3159481.pdf

GAO, J.; FU, H.; ZHOU, X.; CHEN, Z.; LUO, Y.; CUI, B.; CHEN, G.; LIU, J. Comparative proteomic analysis of seed embryo proteins associated with seed storability in rice (Oryza sativa L.) during natural aging. Plant Physiology and Biochemistry, v.103, p.31-44, 2016. https://doi.org/10.1016/j.plaphy.2016.02.026

KADER, A.A.; SALTVEIT, M.E. Respiration and gas exchange. In: BARTZ, J.A.; BRECHT, J.K. (Ed.). Postharvest physiology and pathology of vegetables. New York: Marcel Deckker, 2ed., 2003. p.7-29.

KUMAR, S.P.J.; PRASAD, S.R.; BANERJEE, R.; THAMMINNI, C. Seed birth to death: dual functions of reactive oxygen species in seed physiology. Annals of Botany, v.116, p.663-668, 2015. https:// doi.org/10.1093/aob/mcv098

LAMARCA, E.V.; BARBEDO, C.J. Short storability of Caesalpinia echinata Lam. seeds as a consequence of oxidative processes. Hoehnea, v.39, p.577-586, 2012. http://www.scielo.br/pdf/hoehnea/ v39n4/06.pdf

LAMARCA, E.V.; BARBEDO, C.J. Sensibilidade à dessecação de embriões de Inga vera Willd. formados sob diferentes condições ambientais. Revista Árvore, v.39, p.1083-1092, 2015. http://www. scielo.br/pdf/rarv/v39n6/0100-6762-rarv-39-06-1083.pdf

LAMARCA, E.V.; BONJOVANI, M.R.; FARIA, J.M.R.; BARBEDO, C.J. Germinação em temperatura sub-ótima de embriões de Inga vera sbsp. affinis obtidos sob diferentes condições ambientais. Rodriguésia, v.64, p.877-885, 2013. http://dx.doi.org/10.1590/S217578602013000400015

MELLO, J.I.O.; BARBEDO, C.J.; SALATINO, A.; FIGUEIREDORIBEIRO, R.C.L. Reserve carbohydrates and lipids from the seeds of four tropical tree species with different sensitivity to desiccation. Brazilian Archives of Biology and Technology, v.53, p.889-899, 2010. http://dx.doi.org/10.1590/S1516-89132010000400019

PAGNOTTA, S.E.; BRUNI, F. The glassy state of water: a 'stop and go' device for biological processes. In: POLLACK, G.H., CAMERON, I.L., WHEATLEY, D.N. (Ed.). Water and the cell. Dordrecht: Springer, 2006. p.93-112. 
PAMMENTER, N.W.; BERJAK, P.; FARRANT, J.M.; SMITH, M.T.; ROSS, G. Why do stored hydrated recalcitrant seeds die? Seed Science Research, v.4, p.187-191, 1994. https://doi.org/10.1017/ S0960258500002178

PARISI, J.J.D.; BIAGI, J.D.; MEDINA, P.F.; BARBEDO, C.J. Fungicide and drying effects on the viability of recalcitrant seeds of Inga vera subsp. affinis. Tropical Plant Pathology, v.41, p.177-182, 2016. https://doi.org/10.1007/s40858-016-0084-6

ROACH, T.; BECKETT, R.P.; MINIBAYEVA, F.V.; COLVILLE, L.; WHITAKER, C.; CHEN, H.; BAILLY, C.; KRANNER, I. Extracellular superoxide production, viability and redox poise in response to desiccation in recalcitrant Castanea sativa seeds. Plant, Cell and Environment, v.33, p.59-75, 2010. https://doi.org/10.1111/ j.1365-3040.2009.02053.x

ROQUEIRO, G.; FACORRO, G.B.; HUARTE, M.G.; CELIS, E.R.; GARCİA, F.; MALDONADO, S.; MARODER, H. Effects of photooxidation on membrane integrity in Salix nigra seeds. Annals of Botany, v.105, p.1027-1034, 2010. https://doi.org/10.1093/aob/mcq067

ROQUEIRO, G.; MALDONADO, S.; RÍOS, M.C.; MARODER, H. Fluctuation of oxidative stress indicators in Salix nigra seeds during priming. Journal of Experimental Botany, v.63, p.3631-3642, 2012. https://academic.oup.com/jxb/article/63/10/3631/539391
SANTANA, D.G., RANAL, M. Análise da germinação: um enfoque estatístico. Brasília: Ed. Universidade de Brasília, 2004. 248p.

SANTOS, M.R.O.; BARBEDO, C.J. Deterioration rates of brazilwood seeds (Caesalpinia echinata Lam.) under high temperatures. Hoehnea, v.44, p.449-463, 2017. http://www.scielo. br/pdf/hoehnea/v44n3/2236-8906-hoehnea-44-03-0449.pdf

SILVA, J.P.N.; SALATINO, M.L.F.; CENTENO, D.C.; BARBEDO, C.J.; FIGUEIREDO-RIBEIRO, R.C.L. Implications of the fatty acids and carbohydrate variation during maturation upon Poincianella pluviosa (sibipiruna) seeds storability. Brazilian Journal of Botany, v.40, p.93-101, 2017. https://doi.org/10.1007/s40415-016-0342-3

TAIZ, L.; ZEIGER, E. Fisiologia Vegetal. Porto Alegre: Artmed, 5.ed., 2012. 820 p.

VERTUCCI, C.W.; FARRANT, J.M. Acquisition and loss of desiccation tolerance. In: KIGEL, J.; GALILI, G. (Ed.). Seed development and germination. New York: Marcel Dekker Inc., 1995. p.237-271.

WALTERS, C.; FARRANT, J.M.; PAMMENTER, N.W.; BERJAK, P. Desiccation stress and damage. In: BLACK, M.; PRITCHARD, H.W. (Eds.). Desiccation and survival in plants: drying without dying. Wallingford, CABI Publishing, 2002. p.263-291. 